\title{
HEART OF DARKNESS AND THE FEAR OF GOING NATIVE
}

Anna Reid

Universidad Autónoma del Estado de Morelos

\begin{abstract}
This article studies Joseph Conrad's novel Heart of Darkness (1899-1902) within the context of Imperial Gothic. It examines the darkness behind Empire and will highlight late-Victorian fears concerning Otherness and degeneration. It addresses the silence both within the narrative and within the Imperial mission. There is no dialogue, just Marlow's monologue. Marlow voyages up the river Congo, to a prehistoric time populated by primitive people; nevertheless he also voyages into the heart of the European man and his fear of turning 'savage'.
\end{abstract}

Keywords: Imperial Gothic, Conrad, Degeneration, Darkness, Other.

'To open to civilization the only part of our globe where it has yet to penetrate, to pierce the darkness which envelops whole populations, it is, I dare to say, a crusade worthy of this century of progress' (Pakenham 21). King Leopold II (1835-1909) of Belgium

\begin{tabular}{|l|l|l|l|l|}
\hline Ilha do Desterro & Florianópolis & $n^{\circ} 62$ & p. 055- 073 & jan/jun 2012 \\
\hline
\end{tabular}


addressed the conference on Central Africa in such terms in 1876, the year he established the International African Society and the year in which Queen Victoria (1819-1901) was named Empress of India. ${ }^{1}$ The International African Society went under the auspices of a philanthropic mission; nevertheless, the objective was the exploitation of ivory and later rubber in the Congo region. King Leopold II commended Henry Stanley (1841-1904) to make the Congo region a Belgian colony and in 1885 the region was named the 'Congo Free State' with King Leopold as its Sovereign. According to E.D. Morel, Concessionaire Companies were set up for the 'moral and material regeneration of the natives' (qtd. in Ledger and Luckhurst, 167); however it was a scheme for the exploitation of ivory.

In 1899, two years before the end of the reign of Queen Victoria, Joseph Conrad published his novel Heart of Darkness in three instalments in Blackwood's Magazine. The expected readership of the magazine was white, male, conservative and in favour of Empire (Hampson xxix). It is based in part on Conrad's own experience of going up the river Congo in May of 1890, as told in The Congo Diary and, on the other hand, on Henry Stanley's experiences in the Belgian Congo as depicted In Darkest Africa, or the Quest, Rescue, and Retreat of Emin, Governor of Equatoria (1890). ${ }^{2}$ Heart of Darkness is introduced by an anonymous narrator who is the Manager of a trading Company, accompanied by Charlie Marlow and the other members of the Company (a Director, a Lawyer and an Accountant). ${ }^{3}$ The Company is aboard the Nellie, awaiting the Thames tidal change to embark towards the colonies. The river Thames is at the heart of the British Empire. Historically for Britain, the river Thames is 'an unavoidable presence physically and psychologically' (Schneer ix) and represents the entrance to and exit from the Empire. The first narrator upholds the expectation of the established reader, recalling 
Britain's colonial and imperial past and present with the purpose of lulling the proposed reader into a false sense of stability. He exalts London as being 'the biggest, and the greatest, town on earth' (Conrad 15). The second narrative narrates Charlie Marlow's voyage to the heart of Africa, the so-called Dark Continent and his involvement in one of the Concessionaire Companies and the exploitation of ivory. His contract is to rescue the enigmatic Kurtz from the upper reaches of the river Congo where his methods have become unsound, putting into danger the integrity of the Company. Marlow's first intervention in the novel changes the pitch: 'And this also' (referring to the river Thames), said Marlow suddenly, 'has been one of the dark places of the earth' (18). ${ }^{4} \mathrm{He}$ then recalls the Roman invasion of England, thus insinuating that the river is also primitive and primeval; this is in stark contrast to the first narrator's exaltation of the river's glorious past. He subverts the imperialist view and creates a sense of unease in the reader as to the aim and purpose of the Imperial project. In 1904 Conrad published an essay entitled London River: The Great Artery of England, in which he describes the docks and wharves (symbols of the ever expanding Empire and its economy) on the Thames waterfront as 'a jungle [...]. Dark and impenetrable at night, like the face of a forest, is the London waterside' (qtd. in Ackroyd 198-199). Thus, in relation to Heart of Darkness an analogy is created between the Thames and the river Congo: both are jungles and places of darkness and both are arteries into the heart of an island/continent.

British literature from the last decade of the nineteenth century shares certain similarities and concerns in relation to the question of Empire. These are not necessarily conscious, but rather reflect a national preoccupation with the decline and expansion of Empire and the fear of the Other. ${ }^{5}$ This literature has been termed 'Imperial Gothic' by Patrick Brantlinger. He identifies three main themes 
in Imperial Gothic. These themes are: 'an individual regression or going native; an invasion of civilization by the forces of barbarism or demonism; and the diminution of opportunities for adventure and heroism in the modern world' (Brantlinger 230). Nevertheless, as Punter and Byron point out the term is flexible and is subject to various interpretations (44-49): 'the colonial enclaves of imperial Gothic exist as outposts in the surrounding dark; but what interests the Gothic is not so much the survival of these outposts as the menaces which may come to destroy them, the "return" of the imperial repressed' (Punter and Byron 49). Ever since its origins the Gothic has had an interest in the foreign; however, Imperial Gothic's interest in the foreign or Other becomes a means of projecting contemporary fears at home, creating a mirror effect. There is a preoccupation concerning the relationship between the Empire and her colonies, in particular, the colonized subject (Punter and Byron 39-40). 'The colonised culture is given Gothic treatment as being itself the source of barbarism, temptation and horror' (Procter and Smith 96). The foreign or Other can represent a danger, but it can also be inverted, and the colonizer may be contaminated by the essence of what he fears or desires most. This is one of the elements that Heart of Darkness explores.

This article will examine Heart of Darkness within the context of Imperial Gothic. Brantlinger's assertion that Imperial Gothic introduces a 'diminution of opportunities for adventure and heroism in the modern world' (230) is apparent in Marlow. ${ }^{6}$ As a young boy Marlow was enthralled by the 'blank spaces' (21) on the world map, spaces yet to be populated and 'civilized. However by the time he grows up those spaces are no longer blank; rather they embrace the colours of the European Empire (red, blue, green, orange, and yellow). Thus the spaces for adventure are now reduced, and Marlow is described simply as a 'wanderer' (18), not as an adventurer. ${ }^{7}$ The 
only blank space left is the frozen expanse of the North Pole which embodies negative connotations of failure and European cannibalism from Sir John Franklin's unsuccessful expedition in 1845 aboard the HMS Erebus and the HMS Terror in search for the NorthWest Passage. Marlow thus ventures into the yellow space which represents the Belgian colonies. In the Sepulchral City (Brussels) he joins a Concessionaire Company and before embarking for Africa he has afternoon tea with his Aunt. Once he reaches the river Congo and the Outer Station, he slowly goes up-river, passing by the Central Station, the Inner Station, until he arrives at a remote out-post where Kurtz exploits ivory using unorthodox methods. In response to Brantlinger's definition of Imperial Gothic, neither adventure nor heroism is present in Heart of Darkness. Marlow is simply a cog in the wheel of the Company.

There is no hero and Kurtz, who is seen by some to have ambiguously outstanding attributes, is an antihero, and Marlow's meeting with him is an anticlimax. In addition there is no action, unlike most adventure novels. Rather the emphasis is on waiting, and on the hollowness and futility of any action. When Marlow voyages along the Atlantic coast he sees a man-of war firing into the dark continent: 'Pop, would go one of the eight-inch guns; a small flame would dart and vanish, a little white smoke would disappear, a tiny projectile would give a feeble screech-and nothing happened' (31). ${ }^{8}$ When Marlow is about to reach Kurtz, trapped within the fog on the river Congo, the 'faithless pilgrims' (44) 'were simply squirting lead into that bush' (76). ${ }^{9}$ In both examples the language is childish, 'squirting' giving the impression that the pilgrims are using water pistols, not the Winchesters that Marlow refers to. At the Central Station Marlow observes the so-called pilgrims strolling around, waiting for over a year, reverencing the hope of ivory, a word which 
rings in the air, it is 'whispered... sighed' (44). In an episode at the Central Station Marlow wants to extinguish a fire in a shed, but it is useless as the buckets have holes. At the Outer Station the work of a black chain-gang is again worthless and unimportant and Marlow reflects: 'It might have been connected with the philanthropic desire of giving the criminals something to do' (34). However, the philanthropic concern of Empire has disintegrated and the narrative highlights the darkness behind Empire.

The novel has recurring dichotomies and ambiguities: heroantihero; climax-anticlimax; light-darkness; ebb-flow; seeingblindness; silence-noise. The silence within the narrative reflects that of the Imperial project. There is no dialogue, just Marlow's monologue. Marlow voyages up the river Congo, to a prehistoric time populated by primitive people, nevertheless he also voyages into the heart of the European man and his fear of degeneration and of turning 'savage'. Africa thus becomes a place where European desires, often repressed, are projected. The river Congo represents temptation and Marlow declares that he is charmed by the 'mighty big river... resembling an immense snake uncoiled, with its head in the sea' (22). The narrative is punctuated with pauses, silences, and detached voices which echo through the jungle or are lost in the mists of time and space. The conservative audience that Marlow addresses on the Nellie seems not to hear him; they are indifferent to his story, and the interventions of the anonymous narrator become less frequent and briefer (these interventions decrease from five in the first section, to three in the second, and to just one in the final section). Additionally, these interruptions emphasize the apathy aboard the Nellie, and the lack of interest in Marlow's experiences in the Congo. The first narrator states that Marlow's narratives are 'in the likeness of one of those misty halos that sometimes are made 
visible by the spectral illuminations of moonshine' (18). The haze and mist on the river Thames hides and distorts the reality of Empire: no-one wants to listen to the unspeakable, and Marlow and his monologue become ever more distanced from his supposed audience on the Nellie. In addition, some of Marlow's memories are recalled 'mistily' (114). Moreover, he recalls Kurtz as rising from the ground 'like a vapour exhaled by the earth [...] misty and silent' (105). On returning to Brussels after having rescued the dying Kurtz, Marlow visits Kurtz's Intended in mourning. Her visage 'is surrounded by an ashy halo' (119), thus revealing the undefined nature of Empire and its people. Nothing is seen clearly, yet at one point it seems as the African mist, personified, shouts back. When Marlow's steamboat is enshrouded in fog, 'it seemed as though the mist itself had screamed' (68), contrasting with the silent mist on the river Thames which deadens Marlow's solitary voice.

The publication of Charles Darwin's Origen of Species in 1859 caused great controversy regarding man's evolution throughout the latter part of the nineteenth century. Nevertheless, if man can evolve, the opposite process can occur. Thus, Darwinian theories gave the basis to the concept of racial, cultural and social degeneration. Max Nordau's Degeneration, published in English in 1895, was highly influential in fin-de-siècle thought and explored the decline of Empire. In addition, he argued that the physical body could be marked by certain stigmata 'deformities, multiple and stunted growths in the first line of asymmetry, the unequal development of the two halves of the face and cranium' (qtd. in Ledger and Luckhurst, 2000: 16), deformities which reflected the moral deterioration from within. Degeneration was dedicated to Cesare Lombroso whose L'uomo delinquent (1876) marked the course of criminal anthropology. This text used scientific methods to measure the body, in particular the 
skull, in order to classify degenerate, or criminal types, and whereby physical defeats were 'outward features of the atavistic process whereby the criminal or insane reverted to primitive forms' (Bourne Taylor, 2007: 14). These theories are evident in Heart of Darkness and are also associated with Brantlinger's assertion that Imperial Gothic reveals a fear of individual regression. When he is in Brussels, Marlow's head is measured, although the doctor who measures him states that 'the changes take place inside' (27), indicating a moral degeneration in man when far away from 'civilization. ${ }^{10}$ Physical degeneration is also present and one of the members of the Company is described as having a 'short flipper of an arm' (58), as though he were a seal or a penguin. In addition, on the evolutionary scale there is a similarity between the savage, the criminal and a child: 'the savage has the mind of a child with the passions of a man' (qtd. in Ledger and Luckhurst 324). When having tea in Brussels with Marlow, Marlow's aunt declares that the natives need to be 'wean(ed) [...] from their horrid ways' (28), just as infants are weaned from their mother's milk, thus insinuating that the African natives are child-like and criminally inclined.

Dissolution is another characteristic of degeneration. The men who bombard the steamer with arrows are described as being 'incomplete, evanescent' (77). Kurtz's body gives the impression that it dissolves; his outline is misty, 'like a vapour exhaled by the earth' (105). His indistinct body reflects his moral degeneration, swayed by earthly passions. In the Congo he lacked restraint in the gratification of his various lusts' (95), taking an African lover, and showing brutal instincts. He regresses to the jungle, to the wilderness which 'had taken on him a terrible vengeance for the fantastic invasion' (95). Ironically it is the inverse of Imperialism; he is contaminated. As David Punter asserts in relation to decline in The Strange Case of 
Dr. Jekyll and Mr. Hyde: 'The particular difficulties encountered by English imperialism in its decline were conditioned by the nature of the supremacy... one constantly seen as founded on moral superiority' (Punter 3 ) and Kurtz goes against the repressive nature of the dominant, white culture. Interestingly in both novels the exact crimes committed are shrouded in silence.

Moral degeneration and the fear of turning native are palpable in Marlow's narrative. Fresleven is Marlow's predecessor whom Marlow replaces in the Congo. However, after just two years in the jungle 'engaged in the noble cause' (23), Fresleven changes from being the 'gentlest, quietest creature that ever walked on two legs' (23), to an irrational man who dies in a scuffle over two hens. His cadaver literally dissolves and his bones lie covered by vegetation, thus the natural world dominates the so-called civilized. Similarly, Kurtz is tainted by Africa. He is sent to the Congo by the International Society for the Suppression of Savage Customs and for whom he writes a seventeenpage pamphlet. Marlow considers the pamphlet to be an eloquent appraisal of the natives, yet there is a patent contradiction between what he purports to write and his final exclamation: 'Exterminate all the brutes' (84). Nevertheless, Marlow acknowledges that he must have written it before Africa started to affect his brain, before he started 'to preside at certain midnight dances ending with unspeakable rites' (83), and to adorn the posts surrounding his house with 'heads on the stakes' (94). Thus, for the Company, Kurtz needs to be exterminated as he endangers the colonial enterprise, his methods having become those of the savages; he has been contaminated and is no longer 'European. ${ }^{31}$ Kurtz is finally confined to a stretcher, weighing little more than a child and is likened to a criminal in his regression. Later, when Kurtz leaves the heart of Africa Marlow states: 'I could see the cage of his ribs all astir, the bones of his arm waving. It was as though 
an animated image of death carved out of old ivory had been shaking its hand with menaces at a motionless crowd of men made of dark and glittering bronze' (97). ${ }^{12}$ Like Fresleven, Kurtz does not have a Christian burial and his body, described simply as 'something', is left 'in a muddy hole' (112). It is significant that the three characters in the novel who have names are Fresleven, Kurtz and Marlow. The first two become savage and Marlow comes close to savagery. On confronting Kurtz in the middle of the jungle Marlow threatens him: 'if you try to shout I'll smash your head in' (106), behaving just as Fresleven did fighting over a couple of hens. Nevertheless, Marlow manages to control his outburst to a certain extent and corrects himself; 'I'll throttle you for good' (106). Marlow declares that Kurtz 'had made that last stride [...] I had been permitted to draw back my hesitating foot' (113). Marlow is afraid of being contaminated. He uses a physical description to convey his fear, the smell of dead hippo meat, but it goes far more psychological than a simple fetid stench.

In the novel time stands still and waiting is the key. The crew await the tidal change on the Nellie, the pilgrims wait for ivory in the Central Station, Marlow awaits the arrival of rivets, the harlequin waits for Kurtz and the Intended waits for an idealized Kurtz. However, time doesn't just stagnate, but it regresses in the evolutionary scale. Once Marlow finally goes up-river, after having received his rivets, he declares that it 'was like travelling back to the earliest beginnings of the world' (59). Time returns to 'another existence' (59), to an unknown world. The claustrophobic jungle encroaches upon the river: 'Trees, trees, millions of trees, massive, immense, running up high; and at their foot, hugging the bank against the stream, crept the little begrimed steamboat' (61), recalling the sublime landscapes of Ann Radcliffe, but the sharp-pointed mountain tops are replaced by the jungle's trees, and the steamboat becomes insignificant. 
The steamboat is described as 'a sluggish beetle' in which Marlow 'crawled towards Kurtz' (61). The boat is unable to advance quickly, the air is sluggish, and in terms of degeneration it is interesting that Conrad uses the term to 'crawl', recalling a toddler's first attempts at walking. That is to say, just as the penetration of the jungle is a return to a 'prehistoric earth' (62), the steamboat's progress up river is a regression in man's evolution. ${ }^{13}$

The man who inhabits the jungle is also described as being prehistoric and Marlow marvels at the link between civilized man and the black masses of Africa: 'what thrilled you was just the thought of their humanity-like yours-the thought of your remote kinship with this wild and passionate uproar' (63). Similarly, the members of the black chain-gang that Marlow encounters in the Outer Station are left to 'crawl away and rest' (35), once they are no longer able to work. The metaphor of crawling is again repeated when Marlow finally meets Kurtz. Marlow describes the crawling of his steamer up the Congo to arrive at the Inner Station, but Kurtz has regressed, physically, morally. He is described as being 'not much heavier than a child' who 'crawled as much as the veriest savage of them all' (96). When Kurtz returns to his African rituals one night, Marlow notes that 'He can't walk-he is crawling on all-fours' (105) and the chiefs who come to idolize Kurtz 'would crawl' (95) towards him. The steamboat crawls up the river Congo, while the ivory trickles down towards the Outer Station (37). However, once Kurtz is onboard the steamer and they leave the Inner Station, 'the brown current ran swiftly [...] bearing us down towards the sea with twice the speed of our upward progress' (109). It is as though Africa expels the steamer and its crew, it spits it out from its heart into the wilderness and anonymity of the Atlantic.

The slowing of time is played up by the repetition of words and stutters. Marlow describes the Manager as inspiring 'uneasiness. That 
was it! Uneasiness. Not a definite mistrust-just uneasiness-nothing more. You have no idea how effective such a... a... faculty can be' (42). The use of ellipsis also stalls time, as do the frequent lack of verbs. Words are not spoken as such; rather they are more guttural; they are grunted, jerked, growled, rattled or gabbled and the manager in the Congo is described as a 'chattering idiot' (43). The only character who fills in the unfinished sentences is Kurtz's Intended, but her interjections are lies, a fantasy as she is distanced from the reality of Empire and she does not want to know what happens to man when he is far from 'civilization'. The sham and hollowness of Empire and its subjects is repeated and is reinforced by the dichotomy of noise versus silence. Kurtz is described by Marlow as a 'hollow sham' (110) and the wilderness 'echoed loudly within him because he was hollow at the core' (95).

In contrast to the hollow Europeans, the jungle is personified. Although the theory of evolution dehumanizes the 'lesser' races, it is interesting that in Heart of Darkness the jungle takes on more human attributes than the heartless pilgrims who only think of ivory. The enormous trees are described as 'living' (67), the branches are described as arms and Marlow sees 'the face of the forest' (74), thus creating an analogy between the forest and tribes. At first the jungle appears to be silent, but from within that impenetrable denseness noises come forth from the natural world. Once Marlow sees 'as though a veil had been removed from my eyes' (76), no longer as a European, the jungle comes to life; the branches are now limbs and 'the twigs shook, swayed, and rustled, the arrows flew out of them' (76). The jungle and the Africans are one, indivisible: 'men appeared, as though they had come up from the ground' (96). Kurtz's lover is at one with the jungle and embraces it and the river. Thus, nature is personified and the coastline of Africa is described in ambiguous sonorous terms: 'always mute with an air of whispering' (29). 
However, during the narrative Africa's voice and physical presence becomes more palpable. The surf has a voice, but it is described as 'dangerous... as if Nature herself had tried to warn off intruders' (31). Before embarking on his voyage up-river, there is an insinuation that the jungle might react: 'Perhaps on some quiet night the tremor of faroff drums' (39) might sound. In the Central Station, surrounded by the silent wilderness, Marlow feels that there is something hidden behind the great expanse of trees, unseen inhabitants, unknown mysteries: 'The woods were unmoved, like a mask-heavy like the closed door of a prison-they looked with their air of hidden knowledge' (93). Up-river the silence is punctuated by the rolls of drums and their echoes which seem to resonate off the tops of the trees and on the surface of the river (62). Nature and the impenetrable wall of trees are again described in a series of dichotomies regarding silence and noise: 'a rioting invasion of soundless life, a rolling wave of plants' (54).

Silence and noise are also present in speech, in what is said and in what is left unsaid or unheard; in what is light or darkness. Highlighting the dichotomy between noise and silence is the emphasis on the 'voice, whether of Kurtz, Marlow, or perhaps Conrad himself. In the case of Kurtz 'The man presented himself as a voice' (79). Yet according to the harlequin one does not talk to Kurtz, one just listens to him: it is a monologue. In addition, Kurtz's speech is described in contradictory terms: 'the pulsating stream of light, or the deceitful flow from the heart of an impenetrable darkness' (79). Speech itself degenerates, composed of a series of short, unfinished and unconnected phrases, for example, 'Make rain and fine weatherone man-the Council-by the nose' (56). Ironically these interjections refer to Kurtz, the 'voice', but again silence reigns: 'His name, you understand, had not been pronounced once' (57). Kurtz's final words 'the horror, the horror' (112) are uttered as 'a cry that was no more 
than a breath' (112). These words resonate in Marlow's mind in the Intended's drawing-room as a 'whispered cry' (118). Procter and Smith argue that Kurtz's final words represent the moment when the 'Gothic horror of his own transgressive behaviour intersects with the horror of the colonial project, etched on the reader's memory by the human heads on Kurtz's fence and the exploited black shadows from the chain-gang' (2007: 103). Both Marlow and Kurtz are nebulous characters but both want an audience. Kurtz achieves an audience in the harlequin (91); Marlow's audience on the Nellie is indifferent. Marlow declares in desperation: 'I have a voice too, and for good or evil mine is a speech that cannot be silenced' (63). However, the problem is not so much as to whether he has a voice to not; rather, like Conrad, as to whether he will be listened to or not. Do his words fall on deaf ears? Is the crew on the Nellie interested in the darkness behind the Imperial mission? Given that the crew also are part of a Concessionaire Company ready to sail to the colonies, it would seem not. In addition, there is no interest in the domino set aboard the Nellie, evidence of the exploitation of ivory in darkest Africa and Kurtz's erroneous methods.

Long after Marlow's return to 'civilization', Africa penetrates and haunts the Sepulchral City, Brussels. However, the city is not named and thus represents all European cities. The Imperial mission and the Company represent all Europe, just as the motley harlequin does and 'All Europe contributed to the making of Kurtz' (83). When Marlow visits Kurtz's Intended he recalls the now dead Kurtz on his stretcher and hears 'the beat of the drum, regular and muffled like the beating of a heart' (117). The wilderness rushes forth to occupy the domesticated spaces of Brussels as darkness falls. ${ }^{14}$ Alliteration highlights the sonorous and living quality of the jungle. Within the Intended's drawing-room Marlow hears the 'ripple of the river, 
the soughing of the trees swayed by the wind, the murmurs of wild crowds, the faint ring of incomprehensible words cried from afar, the whisper of a voice speaking from beyond the threshold of an eternal darkness' (121). Marlow states that Kurtz's Intended 'must speak' (120), despite her lack of knowledge of what goes on in the Dark Continent. 'She talked as thirsty men drink' (120) and with each word uttered in her ignorance 'the darkness deepened' (120); a darkness which for Marlow is more palpable and asphyxiating than the darkness in the heart of Africa. In the Intended's drawingroom words conceal and reveal the sham behind the Empire. In the drawing-room Marlow lies and declares that Kurtz's dying words were the Intended's name and not the whispered 'the horror, the horror'. Rather than a screeching cry, meaning is found in the mute whispering which slowly gains potency and reaches its climax in Kurtz's dying statement. This lie produces further dichotomies: sighs and cries, triumphs and unspeakable pain. Marlow's voice is 'muffled' (122). The spoils of Empire are everywhere (the mahogany frontdoor, the Aunt who drinks tea, the sarcophagus-like piano with its keys made of ivory, the ivory-made dominoes).${ }^{15}$ Both the Intended and Marlow's aunt are participants within the Empire, but they expose the sham, the hollowness, the hypocrisy and silence behind it. The question begs, where does the darkness lie? In the Outer Station where the chain-gang dies groaning? In the Inner Station where Kurtz is an idol? On the river Thames? At the heart of Empire? In the Intended's drawing-room? In Kurtz? In Marlow himself? There are no answers to these interrogatives, only yet more uncertainty.

The ambiguous nature of the narrative and the silence within the Imperial mission can perhaps be best captured in Marlow's reflection on the harlequin's tale which concerns his knowledge of Kurtz: 'There was no sign on the face of nature of this amazing tale that was not so 
much told as suggested to me in desolate exclamations, completed by shrugs, in interrupted phrases, in hints ending in deep sighs' (93). Kurtz literally haunts the narrative, from the first time his name is uttered in a kind of silent awe, to long after his death. Marlow describes him as an 'eloquent phantom' (122) and murmurs and whispers echo through the narrative. However, in the Congo, the murmurs are different, they are interrupted by gunfire, dying groans, swarming flies and the ever increasing presence of rolling drums which ricochet through the jungle; words are babbled and lose their meaning. In Heart of Darkness the Europeans are dehumanized and are contrasted with the vivant Africans and the jungle personified. The fear of going native is ever-present and Africa answers back through sounds and gestures, haunting Marlow's memories, the river Thames, the Sepulchral City, comfortable European drawing-rooms and afternoon tea-time. Rather than a regeneration of the native population as proposed by the Concessionaire Companies, the reverse occurs: in his encounter with the unknown the European degenerates morally and physically. Heart of Darkness highlights the late-nineteenth century anxieties about the invasion of civilization by dark, unknown forces, the fear of the moral and social degeneration of man and Empire, and offers a critique of European Imperialism from within.

\section{Notes}

1. Queen Victoria reigned Great Britain from 1837 to 1901 and as monarch she was also the head of the British Empire. By the end of her reign the British Empire was so vast that it was said that the sun never set on it.

2. Stanley's publication 'marked a turning point in the representation of impoverished London as an outpost of Empire' (Forman 106). Africa as the Dark Continent could be used as an analogy for the impoverished London of the turn of the century. This is particularly relevant in relation to Heart of Darkness and to the question as to where the darkness lies. 
3. There is a parallel between the Company that Marlow describes in the Congo and the Company waiting on the Nellie. In both companies the members have generic names and represent European companies in general.

4. This statement recalls William Booth's, the founder of the Salvation Army, assertion made in 1890: 'As there is a darkest Africa is there not also a darkest England? Civilisation, which can breed its own barbarians, does it not also breed its own pygmies?' (qtd. in Ledger and Luckhurst, 46).

5. 'Between 1870 and 1900 , the British empire was extended by 4.75 million square miles, annexing thirty-nine separate areas and adding 88 million new "subjects" for Queen and Empress Victoria, taking her tally to 420 million people [...] empire became a new locus for making the nation cohere [...] which may explain a pervasive sense of panic, of impending doom and imperial decline, that accompanies this era of seemingly unstoppable expansion' (Ledger and Luckhurst 133-134).

6. Marlow can be seen as Conrad's alter ego who 'haunts (his) hours of solitude' (Conrad 10)

7. It is significant that Kurtz's idolater, the 'be-patched' (91) Russian, wears a motley array of colours which reflect the colours of Empire (blue, red and yellow) and is nicknamed the harlequin for his haphazard-and disintegrated-appearance. The maps of the period used certain colours to denote which European countries had which colonies. For example, French colonies were coloured blue, British red, and Belgian yellow.

8. The language used is significant. The word 'dart' recalls the action of arrows.

9. The pilgrims are so called because of the staves they hold. However, they have no religious purpose; they are simply men awaiting riches and personify the sham behind the humanitarian aim of the Company.

10. The sense of futility is emphasized as the doctor does not give any followup to his head measurements on their return to Europe from Africa.

11. Nevertheless the methods employed by Kurtz are in fact refreshing to Marlow. Having seen such disguised darkness and corruption in the voyage upriver, Marlow is almost relieved to see such transparency: 'pure, uncomplicated savagery was a positive relief, being something that had a right to exist-obviously-in the sunshine' (95). 
12. This quote embodies various recurrent analogies concerning bones (human bones, ivory, the domino set on the Nellie) and confinement (cage, enclosure, claustrophobia, silence). It is significant that the un-played domino set on the Nellie is referred to as the 'bones', thus furthering the analogy between human bones, ivory, the Company, death, degeneration, frivolity, and numbers.

13. The steamer is personified, its steam-pipes are bandaged and within its boiler lives a devil (64) it 'gasps' and as she chugs up river she regresses on the evolutionary scale: 'her outlines blurred as though she had been on the point of dissolving' (68).

14. Europe invades and colonizes Africa; nevertheless the only moment that Marlow feels that Europe haunts Africa is when he is witness to Kurtz crawling on the forest floor and he recalls 'the knitting old woman with the cat' (105) who represents fate.

15. Unlike other Imperial Gothic texts these trophies do not haunt the domestic space (Punter and Byron 47-49). Yet the trophies can be rather more macabre, as is qtd. in the article 'Affairs on the Upper Congo', published in The Times, 14 May 1897, in which the trophies are smoked hands (Ledger and Luckhurst 154-156).

\section{References}

Akroyd, Peter. Thames: Sacred River. London: Vintage, 2008.

Bourne Taylor, Jenny. "Psychology at the fin the siècle”, in ed. Gail Marshall, The Fin de Siècle. Cambrige: Cambrige University Press, 2007. 13-30.

Brantlinger, Patrick. Rule of Darkness: British Literature and Imperialism, 1830-1914. Cornell: Cornell University Press, 1988.

Conrad, Joseph. Heart of Darkness with The Congo Diary. ed. Robert Hampson. London: Penguin, 1995.

Forman, Ross, G. 'Empire', in ed. Gail Marshall, The Fin de Siècle. Cambridge: Cambridge University Press, 2007. 91-111.

Hampson, Robert. "Introduction". Heart of Darkness with The Congo Diary. ed. Robert Hampson. London: Penguin, 1995. ix-xliv. 
Ledger, Sally y Roger Luckhurst. The Fin de Siècle. A Reader in Cultural History c. 1880-1900. Oxford: Oxford University Press, 2000.

Pakenham, Thomas. The Scramble for Africa. London: Wiedenfeld and Nicolson, 1991.

Procter, James and Angela Smith. 'Gothic and Empire', in eds. Catherine Spooner and Emma McEvoy, The Routledge Companion to Gothic. London: Routledge, 2007. 95-104.

Punter, David. The Literature of Terror: A History of Gothic Fictions from 1765 to the Present Day, Vol. 2. The Modern Gothic. London: Pearson, 1996.

Punter, David and Glennis Byron. The Gothic. Oxford: Blackwell Publishing, 2004.

Schneer, Jonathan. The Thames: England's River. London: Abacus, 2005.

[Received in 15/12/2011. Approved in 15/06/2012] 
